\title{
AN IMAGE OF AMERICAN MUSLIMS THROUGH UPDIKE'S TERRORIST: A STUDY OF IDENTIFICATION AND REPRESENTATION
}

\author{
Diba Prajamitha Aziz \\ dibaprajamitha@gmail.com
}

\begin{abstract}
In the aftermath of September 9/11 tragedy, an image of Muslim dramatically becomes popular topic and object for the researchers. Although analyses for the most part tend to explain the image of Muslim in negative and stereotypical tendency, the wave of action that expresses positive image of Muslim has surfaced in American society. In that case, this thesis using a novel to see that social phenomena attempted to reveal that an image of American Muslims as represented by Ahmad Ashmawy Mulloy in Updike's Terrorist contributed to endorse an image of Muslim neither as extremist nor as terrorist. To achieve its purpose, firstly this study employs theory of imaginary and symbolic identification from Jacques Lacan. This theory is used to explain the impact of fatherless background, the presence of surrogate father and the influence of another figure on Ahmad. Secondly focusing on an image of American Muslims, theory of representation from Hall is applied. His theory is as a bridge that Muslim can be constructed and represented in the novel. Furthermore, opinions about extremist and moderate Muslim are used to explain those images through characteristics such as thought, action and orientation. The result of the study reveals that the process of identification divides people whom Ahmad had interaction into category of Muslim and non-Muslim group. Muslim group teaches Islamic identity to Ahmad and non-Muslim group plays big role to influence Ahmad to integrate himself into American society. Due to those groups, an identity and image of Ahmad is always related to the other. Focusing on Ahmad's representation as American Muslim, he shows that there are three images such as extremist, transitional and moderate. As a result, through depicting Ahmad as moderate Muslim, Muslim is not terrorist.
\end{abstract}

Keywords: American Muslim, identification, representation, extremist Muslim, moderate Muslim

\section{INTRODUCTION}

September $11^{\text {th }}, 2001$ was a monumental day to Americans because of the unimaginable experience of grief and destruction. According to Khan (2003), "this tragedy made Americans difficult to comprehend the situation, because they think of this event as "heinous crime" (p. 56). It is because, Americans cannot understand why people would aim to do horrible things towards innocent civilians in the name of religion. In the aftermath of the incident, Americans were overwhelmed with shock, anger and hatred, at the same time as Muslims in America became the target of backlash through discriminating experiences such as physical attack or verbal harassment.

Following that day, the term terrorism also became popular. This word unfortunately tended to be used to describe terrorism linked to
Muslims and Islam. Therefore, a stereotyping mindset refers to terrorism as related predominantly with Islam and Muslim. According to Blin (2007), "there are three aspects that convince American to believe that way of thinking" (p. 413). The first aspect is media, because the incident, comment and testimony are broadcast live. While Americans can see, feel and experience the attack with their eyes, they construct feelings of extreme dislike towards the hijackers who are Muslim. The second aspect is symbolic. The World Trade Center was the heart of America's financial center and military establishment. It can be said that launching an attack on the Twin Towers is similar with showing aggression to the rest of America. The third aspect is statistic. Due to the a World Trade Center being a vital building on the central point of business, this incident resulted in a large number of victims. 
Struggling against stereotyping, many American Muslims declared that Muslim does not mean terrorist. One of the examples of how they showed this was a Muslim trust. The project was simple. A Muslim stood and was blindfolded with a sign and accepts hugs. The message of this action is clear. Muslim does not mean terrorist, because Muslim and terrorist are different things. As uploaded on YouTube on 20 March 2015 by The Strangers. By taking place in New York's subway, there were man and woman standing and blindfolding with a sign, "People call me a terrorist and people think I am a terrorist, hug a Muslim.”

One of the literary works which illustrates an attempt at breaking the stereotype of Muslims post $9 / 11$ is the American novel, Terrorist, written by John Updike. This article intends to analyze an image of American Muslim represented as Ahmad Ashmawy Mulloy. He is a second generation of American mother and Muslim migrant. In the absence of father-figure and growing up with non-Muslim American mother, Ahmad declares himself as Muslim. Although he affiliates with a terrorist group, Ahmad in the end leaves the extremist path behind.

In a nutshell, for the most part many researchers conclude their analysis by establishing Ahmad as the image of a terrorist without considering his fatherless background and his American background. Using those backgrounds, this research deals with the presence of a surrogate father-figure, his influence, and how this figure has an effect on representing an image of Ahmad as a moderate American Muslim. Based on the background given above, the main problem of towards and how those influences have effect on his image. This thesis is about the influence of backgrounds such as family and society towards American Muslims and how those influences have an effect on his image.

\section{THEORETICAL FRAMEWORK}

This article is under American Studies, which employs an interdisciplinary approach. In particular, in order to explain the portrait of American Muslims, it employs identification theory to elaborate the influence of others in the formation of self. Having appropriated Lacan's theory of the formation of self, an identification is developed through imaginary and symbolic identification.

According to Lacan (1949/2006) before individuals enter in imaginary identification, they will experience the mirroring stage. It is a phase in which individuals cannot master their body and know nothing about self and other. Moreover, the presence of parents who help them to move, eat and so for this seen as the capability of those individuals to do everything as they wish. This is why this phase is called mirroring stage because it means that individuals mirror their parents as the source of learning about self. That phase presupposes that individuals identify the other in the form of image or perception. That is to say, individuals have an image of what they experience in mirroring stage and directly enter into imaginary identification. To put it briefly, imaginary identification is about how individuals begins to perceive an image of a parental figure as their future self.

In developing self, individuals enter into symbolic identification. The sign of this phase is the acquisition of language. Lacan believes that language is a medium in which human beings represent themselves in such as, so forth will distinguish who we are and show how those systems internalized by those individuals (Lacan, $1949 / 2006$, p. 31). As a process, this symbolic identification is a must in order to integrate into one's society. language and also get information about others through language. The knowledge of the self, other and world in other words is constructed by language and because of language human beings can act as "distinct" people (Sarup, 1996, p. 8). In addition, language is a system of society and culture in one's society. Therefore, this symbolic identification can be a culture, ideology and value of society. According 
to Tyson (2006), "a response of individual to ideologies such as beliefs, values, and biases, its system of government, laws, educational practices, religious tenets, and so forth will distinguish who we are and show how those systems internalized by those individuals" ( $p$. 31 ). As a process, this symbolic identification is a must in order to integrate into one's society. The second theory is representation. Hall (1997) stated that "representation is a process to produce and exchange the meaning of concept in mind through language between members of society" (p. 17). It is a system that links between a concept and language that facilitates humans to refer to the real and imaginary world of object, people and event. The position of language is important because language is a "representational system" to stand for or represent things-ideas, concepts, feelings-to other people (Hall, 1997, p. 1).

To be used in this article, the images of American Muslims are categorized into extremist Muslim, transitional Muslim and moderate Muslim. Each of the images are constructed of characteristics such as thought, action and orientation. Those characteristics differentiate and define among images. According to Baqai (2011), "the extremist is a label of individuals or groups who are religious fanaticism because of justifying everything in the name of religion and tend to employ violence with the purpose of driving their beliefs, ideologies or moral values on others" (pp. 242-243). In a word, the image of extremist Muslims has characteristics, namely narrow thought, destructive action and group orientation.

In order to develop characteristics of transitional image, this study makes use of opinion that an extremist Muslim has the possibility of being a moderate Muslim as long as he internalizes American values and cultures. In other words, transitional image is a transitional stage in which American figures are symbolized as American spirit, value, culture and so forth. Khan (2003) argued, "moderate Muslim is a label of an American who is culturally assimilated with American society, value, norm, law and culture" (pp. 191-192). In relation to this study, American values that takes part in developing transitional image are freedom, individualism and selfreliance.

The moderate is basically opposite of the extremist Muslim. Writing in a special report published by United States Institute of Peace, Maghraoui (2006) stated, "moderate label is accurate in showing the majority of Muslims who oppose violence, respect the government, value Muslim's tradition and reject the message of extremist such as destruction, hate and isolation" (p. 3). To come to the point, the image of the moderate Muslims meant by this study does not stand for an image of American Muslims in general, but moderate Muslim refers to particular American Muslims with specific characteristics such as critical thought, nondestructive action and individual orientation.

\section{DISCUSSION \\ IMAGINARY IDENTIFICATION WITH AMERICAN MUSLIMS}

The focus of this article is Ahmad Ashmawy Mulloy. He is a second generation immigrant. Due to his cultural backgrounds, Ahmad undergoes his double identity. To reveal his identity, Ahmad identifies people based on spiritual identity such as Muslim and nonMuslim through two processes namely imaginary and symbolic identification.

Ahmad in the beginning experiences the mirroring stage. This mirroring phase takes place in Ahmad who is completely interested in his absent-father. The analysis shows that the mirroring stage for Ahmad means two expressions. First, as looking at mirror, Ahmad feels that he is similar to his father due to their physical appearance. Ahmad feels that Omar's shadow can be seen from his physical appearances as in the quote, "A warm, dark shadow ... I get my own personal neatness from him, I am sure" (Updike, 2006, p. 36; ch.1). Second, this mirroring phase has a personal effect on Ahmad. He projects himself onto a Muslim like an absent-father whom Ahmad 
never meets while he lives with a Christian mother. Ahmad is into imaginary identification, while he is steered by an image and perception about his father. The image and perception of Omar makes Ahmad differentiate people based on two characteristics. First, it is Muslim. Second, physically the person must look like a Middle-Easterner.

This imaginary identification in the end guides Ahmad to substitute the absent father for surrogate father-figures. These figures have similar images such as the immigrant and Muslim. They are Rashid and Charlie. In general, they have function of influencing Ahmad in imbuing his Muslim identity with an antiAmerican's thought. While Rashid sticks closely to Quranic teachings and encourages Ahmad to practice the teachings consistently, Charlie, while supporting him by recruiting him as a truck driver, leads him in a different direction by providing the 'hooker' so that Ahmad commits a sinful action against an Islamic principle. To come to the point, Rashid is more consistent in promoting Islamic values while Charlie is more contradictory in practicing Islamic teachings.

\section{SYMBOLIC IDENTIFICATION NON-MUSLIM AMERICANS}

Ahmad cannot alienate himself from American society. The fact that he lives in America and never goes out of the States reveals that unconsciously Ahmad internalizes American values. Therefore, Ahmad is already American. Even if he denies his American blood, he cannot separate himself from American society and isolate Islamic point of view from American influence.

The analysis of symbolic identification is symbolized by American figures who are nonMuslim. They are Teresa Mulloy, Jorlyeen Grant and Jack Levy. In general, they have an effect on Ahmad, which is replacing the strict standpoint with a relativistic point of view. In addition, they also integrate Islamic principle into American values. Particularly, these figures have an influence on Ahmad in different ways, such as Teresa who tends to implant freedom, Jorlyeen who speaks for individualism and Jack who stands for self-reliance.

\section{REPRESENTATION OF AHMAD ASHMAWY MULLOY}

Based on the result of analysis on identification, the image of Ahmad is attached to the figures whom he follows. Therefore, it is possible for Ahmad to have more than one image. In view of that, this section will discuss how Ahmad experiences three images of the American Muslim. They are extremist, transitional and moderate Muslim. Each of the images has particular characteristics consisting of thought, action and orientation. Those traits differentiate one image to another image. Although Ahmad has three images, these representations are seen as a process for Ahmad to become a moderate Muslim.

In general, Ahmad represents extremist Muslim due to attaching to terrorist group. The novel shows that the part of terrorist group is represented by Rashid. In particular, Ahmad fills in for the posse of extremists, because he fits in three characteristics.

First, his characteristic is narrow thought. This way of thinking is from a literal interpretation of the Quran and taking binary opposition as a point of view. The result of those attitudes constructs a single interpretation of the Quranic verse and radical view as a way of thinking. The narrow thought, for example, is reflected on dialogue between Ahmad and Jorlyeen (Updike, 2006, p. 68 ; ch. 2). This quotation speaks about Ahmad who says an unbeliever as 'kafir.' Due to this term, this unbeliever is enemy and legal target to be killed. From that dialogue, narrow thought is manifested by separating people into Muslim and non-Muslim. In short, this narrow thought represents extremist as religious fanatic.

Second, the characteristic is destructive action. This action is from narrow thought which divides 
the world into western and Muslim category. This categorization puts the western world as the oppressor towards the Muslim world. As the result, destructive action is in retaliation for that sentiment. Ahmad represents this characteristic because he participates in a plot to make an explosion. The novel shows that Ahmad drives a truck that is full of dangerous chemical to perform self-destruction (Updike, 2006, p. 294; ch. 4).

Third, the characteristic is group orientation. Extremist Muslims exist in the name of a group. Following that argument, extremist Muslims live in an organization with a system, member and a place. The novel illustrates the extremist organization through the role of member. Rashid and Charlie is the masterminds. The figures such as "operative, soldiers, units" are the technician of the truck and the bomb specialist (Updike, 2006, p. 246; ch. 4). Ahmad is "the driver", an executor (Updike, 2006, p. 245; ch. 4). Maurice is a fundraiser who collects donation of money (Updike, 2006, p. 199; ch. 4). This group makes use of a mosque as a place to spread and maintain their existence. Due to this system, Ahmad cannot act based on a personal decision. Ahmad will act in the name of the group to proceed group orientation.

Later on, the image of this section is transitional, because the experience of Ahmad in this phase will move Ahmad from extremist to moderate Muslim. The signal of this phase is Ahmad begins contemplating and hesitating about the influence of Rashid and Charlie. It is because Ahmad has contact with Americans. They are Teresa Mulloy, Jorlyeen Grant and Jack Levy. The result of that interaction turns Ahmad to reevaluate his thought, action and orientation based on his personal consideration and intention.

In general, there are three characteristics, which influence the thought, action and orientation. They are self-freedom, which is from American freedom. This characteristic influences on Ahmad in the way of thinking; Critical thought which is from individualism. This characteristic focuses on Ahmad who has critical thinking based on individual thought, consideration and judgment. This thought in some ways plays a role as a determinant factor to change from destructive action to non-destructive action; the last is self-help. This characteristic pays attention to the role of Ahmad as the core of consideration, judgment, decision and action. One example of self-help is the moment Ahmad turns destructive plot into non-destructive action (Updike, 2006, p. 306; ch. 5).

Ahmad represents his image as moderate Muslim, because he reflects moderate characteristics. They are critical thought, nondestructive action and individual orientation. The explanation will be discussed separately and briefly.

First, the characteristic is critical thought. This characteristic can be seen from the decision of whether to press the detonator or leave the detonator. In the end, he decided not to push the button, because Jack Levy "wants to die" and the Quran prohibits suicide and destruction (Updike, 2006, p. 306; ch. 5). This decision means that Ahmad does not merely follow what Rashid tells him to do, but Ahmad employs his thought to face the situation in a critical way. In addition to the example of critical thinking, Ahmad dares to ask the meaning of "infidels" (Updike, 2006, p. 76; ch. 3); Ahmad asks about his "delivering" (Updike, 2006, p. 76; ch. 3); and he has disagreement about the incident of "NineEleven" (Updike, 2006, p. 187; ch. 3). These three events seem show that Ahmad internalizes and practices critical thought.

Secondly, the characteristic is non-destructive action. A moderate Muslim is in the position to reject and oppose any form of violence and destruction. The novel shows that Ahmad principally believes in non-destructive action. Ahmad represents non-destructive action, because he believes in jihad means no war. Therefore, Ahmad believes jihad is an inner struggle. As represented by the quote, "Jihad 
doesn't have to mean war ... it means striving, along the path of God ... inner struggle" (Updike, 2006, p. 149; ch. 3). This inner struggle means that an individual is always trying to be a better Muslim by doing religious worship and improving the goodness. From analyzing jihad as inner struggle, it can be said that Ahmad speaks for Moderate Muslims who believe in God that supports creation rather than destruction. In other words, Ahmad represents non-destructive action and rejects terrorism.

Third, the characteristic is individual Orientation. This orientation can be seen from Ahmad who does not press the detonator and does not participate in the destructive plot. Those attitudes show that Ahmad has a different orientation with Rashid. While by doing destructive action Rashid aimed at making statement to the Western world, by doing destructive action Ahmad thinks that he will not obey the God by allowing Jack to have suicide by dying with him (Updike, 2006, p. 306; ch. 5). Therefore, his decision not to press the detonator shows that hat he already makes up his mind based on critical thinking, personal considering and individual feeling. Ahmad is free from group orientation can be seen at quote, "reassuringly he lifts the fingers of his right hand from the steering wheel" (Updike, 2006, p. 307; ch. 5). That simple quote suggests the expression of independence from another people. In other words, individual orientation is represented as Ahmad who does something because of following his personal aim.

\section{CONCLUSION}

The process of identification identifies two groups. They are the Muslim and non-Muslim groups. The Muslim group consists of Rashid and Charlie. They in general instill AntiAmerican though in Ahmad. The Non-Muslim group consists of Teresa, Jorlyeen and Jack. They fill Ahmad with American values. In other words, American values will broaden their horizon which has the potential of making them more moderate in dealing with others who are NonMuslim Americans.
Furthermore, the findings on representation show that an American Muslim has the possibilities of being either an extremist or moderate depending on whom they get along with. American Muslim is not basically an extremist. In a nutshell, this novel represents an effort to against a stereotype of Muslim by depicting moderate as an image of American Muslim as represented by Ahmad Ashmawy Mulloy. Therefore, being Muslim does not mean you are definitely a terrorist.

Based on the portrayal of American Muslims, Terrorist presents two points. First, terrorism is the problem of humanity. In addition, secondly, there is no religion supporting terrorism. The argumentation can be seen from the representation of Muslims as vulnerable figures that the terrorist groups influence to act in the name of Islam. As a result, many Americans only see themselves as victims and ignore the fact that American Muslims also suffer from the act of terrorism.

\section{REFERENCES}

Baqai, H. (2011). Extremism and Fundamentalism: Linkages to Terrorism Pakistan's Perspective. International Journal Of Humanities And Social Science 1.6 (2011): 242-248.

Blin, A. (2007). The United States Confronting Terrorism. In G. Chaliand and A. Blin. (ed.) and Trans. by E. Schneider, K. Pulver and J. Browner, The History of Terrorism from Antiquity to Al-Qaeda. Berkeley: California UP.

Hall, S. (1997). Introduction. In S. Hall (ed.), Representation: Cultural Representations and Signifying Practices. London: SageThe Open University.

Khan, A. (2003). Islam, Muslims, and America: Understanding the Basis of Their Conflict. New York: Algora Publishing.

Khan, M. A. M. (2003). Constructing the American Muslim Community. In Y. Y. Haddad, J. I. Smith and J. L. Esposito (ed.) Religion and Immigration: Christian, Jewish and Muslim Experiences in the Unites States. Walnut Creek: AltamiraRowman \& Littlefield. 
Lacan, J. (2006). The Mirror Stage as Formative of the- $I$ Function as Revealed in Psychoanalytic Experience. In Jacques Lacan ECRITS the First Complete Edition in English. (Trans. by B. Fink, H. Fink and R. Grigg), pp. 75-81. New York: W. W. Norton \& Company.

Maghraoui, A. M. (2006). American Foreign Policy and Islamic Renewal. United States Institute of Peace Special Report 164 (2006): 1-12.

Sarup, M. (1996). Identity, Culture and the Postmodern World. In T. Raj and P. Brooker. Edinburgh: Edinburg UP.
Youtube.com. (2015). The Strangers. "Blind Trust Social Experiment New York." The Strangers. Retrieved on 20 Mar. 2015 from https://www.youtube.com/watch? $\mathrm{v}=\mathrm{K} 3 \_\mathrm{eGgPT}$ tos

Tyson, L. (2006). Critical Theory Today: A UserFriendly Guide (2nd ed). New York: Routledge-Taylor \& Francis.

Updike, J. (2007). Terrorist. Alfred A. Knopf. Penguin Books. 